\title{
«Российская Древлеправославная церковь Христова Белокриницкой иерархии» - юрисдикции «епископа» Алимпия (Вербицкого): история возникновения и современное состояние
}

\author{
Павел Бочков \\ Кафедра теологии и христианской коммуникации, Межрегиональная Академия управлением персонала, Украина \\ ORCID 0000-0002-3218-6706 \\ frpavel@inbox.ru
}

\begin{abstract}
rev. Pavel Bochkov, "The Russian Ancient Orthodox Church of Christ of the Belokrinitskaya Hierarchy" - the jurisdiction of "bishop" Alimpiy (Verbitsky): history of origin and current state, Elpis, 23 2021: 63-67.

rev. Pavel Bochkov, „Rosyjska Stara Cerkiew Chrystusa Hierarchii Białokrynickiej” - jurysdykcja „,biskupa” Alimpiusza (Wierbickiego): historia powstania i stan obecny, Elpis, 23 2021: 63-67.

Abstract: The article tells about the history of the emergence of a small Old Believer jurisdiction that emerged in 2010 against the background of administrative turmoil and crisis within the Russian Orthodox Old Believer Church. A small group of believers, united by the Old Believer Bishop Alimpiy (Verbitsky), still exists and conducts its religious activities on the territory of Russia and Ukraine. It is also represented on the Internet.

Streszczenie: Artykuł opowiada o historii powstania małej jurysdykcji staroobrzędowców, która pojawiła się w 2010 roku na tle zawirowań administracyjnych i kryzysu wewnątrz Rosyjskiej Prawosławnej Cerkwi Staroobrzędowej. Niewielka grupa wiernych, zjednoczona przez biskupa staroobrzędowca Alimpiusza (Wierbickiego), nadal istnieje i prowadzi swoją działalność religijną na terenie Rosji i Ukrainy. Jest ona również obecna w Internecie.

Аннотация: В статье рассказывается о истории возникновения малочисленной старообрядческой юрисдикции, появившейся в 2010 году на фоне административных нестроений и кризиса внутри Русской православной старообрядческой церкви. Незначительная группа верующих, объединенных старообрядческим епископом Алимпием (Вербицким), и в настоящее время существует и ведет свою религиозную деятельность на территории России и Украины. Она также представлена и в сети «интернет».
\end{abstract}

Keywords: Alimpiy (Verbitsky), Old Believers, schism, non-canonical jurisdictions

Słowa kluczowe: Alimpiusz (Wierbicki), staroobrzędowcy, schizma, jurysdykcje niekanoniczne

Ключевые слова: Алимпий (Вербицкий), старообрядчество, раскол, неканонические юрисдикции

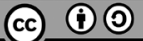

Во второй половине 2000-х гг., в самой крупной старообрядческой поповской юрисдикции - Русской Православной Старообрядческой Церкви (РПСЦ) (известной также как церковь старообрядцев, приемлющих Белокриницкую иерархию), возникло разделение, приведшее к возникновению новых неканонических структур, одной из которых стала «Российская Древлеправославная церковь Христова Белокриницкой иерархии» (РДЦХ БИ).

События, предшествовавшие возникновению нового раскола, связаны с избранием нового Предстоятеля РПСЦ, старообрядческого Митрополита Московского и всея Руси Корнилия (Титова), которое состоялось 18 октября 2005 года в Москве (Izbranie Predstoâtelâ Russkoj Pravoslavnoj Staroobrâdčeskoj Cerkvi, 2006). До своего возведения в сан митрополита Корнилий (Титов) всего несколько месяцев был епископом Казанским (Kratkaâ biografiâ Vysokopreosvâsennejšego
Korniliâ, Mitropolita Moskovskogo i vseâ Rusi, 2006, s. 120) и еще не успел проявить себя на ниве церковного служения в должной мере, и, как следствие, не имел достаточного количества соработников и симпатизирующих ему клириков. На фоне своего харизматичного предшественника митрополита Андриана (Чертвегова) (Preosvyashchenneyshiy Andrian, Mitropolit Moskovskiy $i$ vseya Rusi. Nekrolog, 2005; 546 dnej staroobrâdčestva $v$ XXI veke, 2006), только недавно рукоположенный в сан епископа Корнилий (Титов) выглядел осторожным и скромным иерархом. Первые его шаги на посту предстоятеля РПСЦ вызвали критику со стороны части верующих и клириков, усмотревших в его политике малое внимание к вопросам внутренней жизни РПСЦ (Naša Cerkov' v krizise, 2007), во взглядах - экуменизм, а затем и предательство идеалов РПСЦ и старообрядчества в целом. В преддверии Собора РПСЦ 2007 года появилось «Открытое письмо духовенства, иночеству- 
ющих и мирян Освященному Собору РПСЦ по поводу развития ереси экуменизма в старообрядческой среде», в котором ряд клириков и мирян указали на вышеперечисленные тенденции (Barmin Mihail. Sobor rešil problemu!? - vskryv veny Cerkvi, 2007, s. 4 - 5).

«Одновременно с этим в Иркутско-Амурской и всего Дальнего Востока епархии РПСЦ возник конфликт епископа Германа (Савельева) с иереем Константином Луневым (г. Владивосток) относительно вопроса возможности моления с еретиками и с другими христианами-старообрядцами Приморского края относительно церковной Соборности. На внеочередном Епархиальном Съезде Дальневосточной епархии РПСЦ, состоявшемся весной 2007 года в с.Суходол Приморского края, епископ Герман (Савельев) был отстранен от управления епархией, которая перешла под прямое управление митрополита Карнилия (Титова). Со своей стороны, епископ Герман не признал решения Съезда и запретил в служении семерых из девяти священнослужителей епархии, которые в свою очередь не подчинились решению отстраненного епископа. Освященный собор, проходивший 16-19 октября 2007 года не только ничего не решил в дальневосточном вопросе, но напротив, отказ митрополита Корнилия прочесть публичное исповедание веры вызвало негативную реакцию у дальневосточной делегации, которая покинула Собор. Покинувшие Собор 18 октября объявили о разрыве молитвенного общения с РПСЦ, 9 ноября 2007 года о разрыве молитвенного общения с РПСЦ объявил и епископ Герман. 13 ноября под давлением комиссии РПСЦ, посетившей г. Хабаровск, он объявил о возвращении в РПСЦ, но 20 ноября в г. Москве он объявил о прерывании молитвенного общения с митрополитом Корнилием и возглавил «Собор» ДЦХ (Древлеправославной Церкви Христовой - прим. свящ. П. Бочкова) в Москве (в Алтуфьеро)» (Drevlepravoslavnaâ Cerkov' Hristova (Belokrinickaâ ierarhiâ)).

В 2007 году состоялся Собор РПСЦ, на котором, в числе критиков, выступил инок Алимпий (Вербицкий) осудив деятельность митрополита Корнилия, усмотрев в его официальных встречах и действиях уклонение в ересь и экуменизм. Кроме того, инок обвинил митрополита в тайных переговорах с представителями Русской Православной Церкви Московского Патриархата (РПЦ МП) на предмет возможного соединения (Alimpij (Verbickij), inok. Otkrytoe pis'mo Osvâsennomu Soboru Russkoj Pravoslavnoj Staroobrâdčeskoj Cerkvi). Сам митрополит Корнилий (Титов) «в своих выступлениях не раз признавал допущенные им по неопытности ошибки во время межконфессиональных контактов и так называемого «диалога» с РПЦ МП» (Ezerov i Šiškin, 2007, s. 10). Мысли, выраженные Алимпием (Вербицким) (Ezerov i Šiškin, 2007, s. 11) вполне разделяли несколько клириков РПСЦ, деятельных мирян, представителей старообрядческой журналистики. В частности, главный редактор старообрядческого журнала «Общий Дом» Михаил Бармин из Нижнего Новгорода опубликовал пространную статью с жесткой критикой действий руководства РПСЦ и лично митрополита Корнилия (Титова) (Barmin, 2007). В своей критике М. Бармин особое внимание уделил новшествам, которые стали происходить в РПСЦ сразу же «после избрания митрополита. Спустя всего месяц был отправлен в отставку издательский отдел, сформированный при митрополите Андриане, затем Рогожское покинули настоятель Покровского собора протоиерей Иоанн Думнов, главный архитектор Алексей Синельников и другие. Параллельно с этими событиями происходили необычно частые и близкие встречи с новообрядческими архиереями. Без традиционного соборного обсуждения, на Совете митрополии была создана комиссия по диалогу с РПЦ МП, наличие которой впоследствии вызвало большие потрясения и раздоры» (Barmin, 2007, s. 3). Вследствие критики митрополита Корнилия и конфликта в Дальневосточной епархии возникла новая юрисдикция во главе с епископом Германом (Савельевым) под наименованием «Древлеправославная Церковь Христова (Белокриницкой иерархии)» (Barmin, 2007 , s. 6). Однако сами последователи новой юрисдикции отметили, что собор их юрисдикции от 20.11.2007 г. «не говорил о создании новой конфессии, но четко указал свое правопреемство» (Eliseev, 2007, s. 64).

По состоянию на конец 2007 г. данная юрисдикция представляла собой довольно крупную группу общин и клириков и насчитывала «в своих рядах одного епископа и восемь священников (протоиерей Елисей Елисеев, являющийся икономом - управляющим делами Д[альне]В[осточной] епархии, протоиерей Георгий Иванов - иконом Московской епархии, протоиерей Никола Спижевой (Хабаровск), иерей Александр Шестаков (Бурятия), иерей Константин Лунев (Приморье), иерей Сергий Боголюб (Амурская область), Александр Черногор (Рязанская область), иерей Виктор Иванов (Читинская область), инок Алимпий (Вербицкий), а также порядка 20 церковных общин и религиозных групп (не менее десятка общин на Дальнем Востоке РФ, две в Рязанской области, домашний храм священника Георгия Иванова, а также малочисленная группа в Москве и Подмосковье)» (Drevlepravoslavnaâ Cerkov' Hristova (Belokrinickaâ ierarhiâ)). В ответ на уклонение в раскол, РПСЦ на Совете Митрополии в феврале 2008 г. издала постановлением, в котором признала новосозданную юрисдикцию «раздорническим сообществом», к которому обратилась с призывом к покаянию и возвращению в состав РПСЦ (Obraŝenie Episkopov Cerkvi Hristovoj, 2008), продлив при этом наложенные прещения на ряд критиков митрополита Корнилия (Postanovlenie Soveta Mitropolii Russkoj Pravoslavnoj Staroobrâdčeskoj Cerkvi, 2008).

В последующие несколько лет данная юрисдикция разделилась на несколько непримиримых по отношению друг к другу партий (Postanovlenie Soveta Mitropolii Russkoj Pravoslavnoj Staroobrâdčeskoj Cerkvi, 2008; Razdory v RPSC XXI vek. O sovremennoj specifike deleniâ Cerkvi na učaŝuû i učimuû, 2013), одной из которых стала крайне малочисленная община верующих, 
объединенных вокруг священника Александра Черногора и инока Алимпия (Вербицкого). Однако уже в 2010 г. между ними произошел раздор по «богословскому вопросу о степени причастности еретиков 2-го и 3-го чина к Церкви Христовой, в результате чего стороны анафематствовали друг друга» (Rossijskaâ Drevlepravoslavnaâ Cerkov' Hristova (Belokrinickaâ ierarhiâ)). В результате и эта группа распалась на две части, одну из которых возглавил инок Алимпий (Вербицкий).

Биография инока Алимпия (Вербицкого) изложена им самим на различных ресурсах и в изданиях его юрисдикции, однако и представители РПСЦ подробно излагают некоторые детали его жизненного пути. В миру - Юрий Александрович Вербицкий. Родился в 1965 году в г. Евпатория, в Крыму в греческо-польской семье (Razdory v RPSC XXI vek. O sovremennoj specifike deleniâ Cerkvi na učaŝuû i učimuû, 2013, s. 17). С юности увлекся графикой и иконописью. С середины 1980-х гг. стал профессионально заниматься иконописью, трудился в храмах Русской Православной Церкви. В частности, им были написаны иконы для иконостасов православных храмов в г. Сегеже (Республика Карелия, 1986 г.) и г. Калининграде (1987 г.). Его труды и таланты были замечены архиепископом Смоленским и Калининградским Кириллом (с 2009 г. - патриарх Московский и всея Руси, Предстоятель Русской Православной Церкви). Архиепископом Кириллом он был приглашен на должность епархиального иконописца Смоленской епархии. В этом качестве им был расписан домовой храм архиепископа. По его «архитектурным проектам было построено несколько храмов: в Монастырщине, в Сафоново, в Ельне» (Verbickij, 2010, s. 21). Кроме того, Вербицкий фактически стал клириком Смоленской епархии Русской Православной Церкви, так как у архиепископа Кирилла «был посошником, а в 1988 г. принял от него рясофорный постриг» (Verbickij, 2010 , s. 21). В том же году, согласно исследованиям представителей РПСЦ, Вербицкий «резко пересматривает своё отношение к новообрядчеству, вдруг узнаёт о безблагодатности обливательного крещения и заново крестится трёхпогружательно у единоверческого священника о. Иринарха (Денисова) в Михайловской слободе под Москвой. Он же постригает Юрия Вербицкого в монахи с именем Алимпий» (Razdory v RPSC XXI vek. O sovremennoj specifike deleniâ Cerkvi na učaŝuû i učimuû, 2013, s. 17). Однако сам Алимпий (Вербицкий) утверждает, что принял в единоверческой общине лишь таинство Крещения: «Осенью того же года, я ушел от архиепископа Кирилла и присоединился 2-м чином, через миропомазание и отречение от никонианской ереси, к нашей святой Русской Православной Старообрядческой Церкви, где и был пострижен в монашество. Постриг совершил митрополит Алимпий (Гусев). Монашество я принял в возрасте 22-х лет» (Verbickij, 2010, s. 21). В другом своем тексте он утверждает, что в возрасте 23-х лет (Portfolio staroobrâdčeskogo episkopa Alimpiâ Verbickogo, s. 3). В 1996 г. он поселился в лесу в Рязанской области, где обустроил небольшой скит, в котором прожил 20 лет. «На жизнь зарабатывал иконописанием и продолжал штудировать источники церковной письменности» (Portfolio staroobrâdčeskogo episkopa Alimpiâ Verbickogo, s. 3). Несмотря на удаленность от центра духовной и административной жизни РПСЦ в Рогожском посёлке в Москве, инок Алимпий живо интересовался событиями в жизни старообрядчества, резко реагируя (в письменной форме) на некоторые факты, связанные с отступлением от чистоты вероучения и благочестия (Verbickij, 2010, s. 23]. Оппоненты Алимпия (Вербицкого) утверждают, что в это же время ряд клириков РПСЦ попали под его влияние, вследствие чего были запрещены в служении: «несколько молодых священников, попавших под влияние инока Алимпия в 1990-е, были запрещены в служении митрополитом Алимпием и с тех пор не служат. Среди них о. Александр Кукушкин (Рязань, впоследствии священноинок Агапий), о. Александр Илющенко (Клинцы), о. Симеон Семёнов (с. Микварово Кировской области), о. Михаил Ниякий (священноинок Макарий - служил в Большом Мурашкино и Николо-Улейминском монастыре)» (Razdory v RPSC XXI vek. O sovremennoj specifike deleniâ Cerkvi na učaŝuû i učimuû. s. 17). В это же время, инок Алимпий продолжал заниматься иконописью, трудился над росписями храмов, оформлял старообрядческие издания. В 2004 - 2007 году являлся членом Канонической комиссии «РПСЦ при митрополите, откуда был исключен на Освященном Соборе 2007 года. Одним из вопросов, по которому он делал доклад на Соборе 2005 года, была практика допуска мирян к исповеди и причастию во время между постами» (Razdory v RPSC XXI vek. O sovremennoj specifike deleniâ Cerkvi na učaŝuû i učimuû. s. 18).

Оставшись в середине 2010 года единственным духовным лицом, во главе группы единомышленников, не имея ни одного священнослужителя для удовлетворения нужд общины, Алимпий (Вербицкий) стал искать возможности для рукоположения в священный сан, обосновывая такой шаг на примерах из истории старообрядчества, когда некоторые старообрядцы принимали посвящения от новообрядцев, т.е. в РПЦ. Итогом этих поисков стали контакты с представителями неканонических малочисленных юрисдикций с довольно либеральной идеологической направленностью.

«B середине июня 2010 г. епископ Макарий (Мамонтов) первым вступил с нами в диалог. Он заявил о правоте Староверия и о необходимости покаяния новообрядческой церкви за гонения на Старую Веру. Выяснилось, что епископ Макарий знаменуется только двоеперстно, служит по старым книгам и имеет правильное трех-погружательное крещение. Он с пониманием отнесся к критической ситуации в нашей Церкви и выразил готовность совершить архиерейскую хиротонию. По этому случаю мы созвали внеочередной Освященный Собор (12.07.2010), на котором было решено обратиться за хиротонией к еп[ископу] Макарию, при условии, если подтвердится подлинность его сана. В случае неудачи постановили «изыскать другие воз- 
можности восстановления епископства нашей Церкви»») (Arkhiyereyskaya khirotoniya svyashchennoinoka Alimpiya Verbitskogo, s. 13).

На тот момент «епископ Чеховский и Ковровский» Макарий (Мамонтов), состоял в неканонической группе известной как «Истинно-Православная Церковь, Южнороссийская митрополия» («Православная Российская Церковь») «митрополита» Кириака (Темерциди). Данная группа на протяжении всей недолгой истории своего существования охотно совершала многочисленные «архиерейские посвящения», вследствие чего в настоящее время к ней возводят свое преемство несколько десятков неканонических «иерархов», действующих в странах постсоветского пространства (Bočkov, 2018, s. 68-76). Исследовав историю рукоположений в данной группе, инок Алимпий (Вербицкий) пришел к выводу о подлинности данных рукоположений и троекратном погружательном крещении «епископа» Макария (Мамонтова) и «митрополита» Кириака (Темерциди) (Bočkov, 2018, s. 16-17). В результате 7 июля 2010 года вышеназванные лица совершили хиротонию Алимпия (Вербицкого) в сан «епископа Рязанского и Тумского для общин Древлеправославной Церкви Христовой Белокриницкой иерархии» (Stavlennaâ gramota № 74 ot 07.07.2010 g. Kopiâ. Pečat'. Podpisi.), то есть без иерархического или административного подчинения группе «митрополита» Кириака (Темерциди). Незадолго до этого, Макарий (Мамонтов) совершил диаконскую и пресвитерскую хиротонии над иноком Алимпием (Вербицким).

Факт принятия рукоположения в неканонической и к тому же новообрядческой юрисдикции, в очередной раз расколол и без того малочисленную группу последователей Алимпия (Вербицкого), в результате чего он остался в совсем тесном кругу единомыленников. Его критики из РПСЦ утверждали в 2014 г.: ««Паства» его состоит не более чем из пяти последователей, большинство из которых банально живут в непосредственной близости от него и не имеют другой альтернативы» (Razdory v RPSC XXI vek. O sovremennoj specifike deleniâ Cerkvi na učaŝuû i učimuû, 2013, s. 19). В ответ на критику, в старообрядческом сегменте сети «интернет» «епископ» Алимпий (Вербицкий) заявил о своей верности каноническому порядку: «Я, Алимпий, епископ Российской Древлеправославной Церкви Христовой Белокриницкой иерархии, опровергаю высказывания хулителей Церкви и открыто заявляю, что анафематствую все без исключения древние и новые ереси, а в особенности, никонианскую ересь и ересь религиозной толерантности. Руководствуясь Священным Преданием, я последовательно анафематствую митрополита Корнилия (Титова), патриарха Кирилла (Гундяева), а также все существующие разновидности новообрядчества и единоверия. Воспользуюсь словами священномученика и исповедника протопопа Аввакума: «никониан за все их коби еретические анафеме трижды предаем и держим от отец преданное все»!» (Verbickij, 2010, s. 26).
Уже 18 июля 2010 г. Алимпий (Вербицкий) созвал предсоборное совещание, на котором подтвердил правильность принятого решения о получении хиротонии и изменил свой титул на «епископ Московский» (Postanovlenie črezvyčajnogo predsobornogo soveŝaniâ Drevlepravoslavnoj Cerkvi Hristovoj Belokrinickoj ierarhii 18 iûlâ 2010 g.). 25 августа того же года, на очередном предсоборном совещании, его группа усвоила себе наименование: «Российская Древлеправославная церковь Христова Белокриницкой иерархии» (Postanovlenie črezvyčajnogo predsobornogo soveŝaniâ Drevlepravoslavnoj Cerkvi Hristovoj Belokrinickoj ierarhii 25 avgusta 2010 g.).

Несмотря на обретение «иерархии», юрисдикция не приступила к активной организации новых приходов и привлечению новых членов в свою группу, решив сосредоточиться на внутренней богослужебной жизни. В Рязанском скиту был оборудован алтарь в домовой церкви, и стали совершаться регулярные богослужения, «во всем стараясь придерживаться древних церковных традиций, ныне забытых даже в старообрядческой среде: ночные богослужения, натуральные вещества для литургии и освещения, неспешные знаменные песнопения, священнические облачения старинного покроя» (Verbickij, O našem upovanii). Регулярная богослужебная жизнь немного сплотила последователей, которые вскоре создали «Покровскую общину. 18 сентября 2011 года еп[ископ] Алимпий рукоположил диаконом Павла Мефодиевича Иванова. 13 ноября 2011 года еп[ископ] Алимпий совершил иноческий постриг Людмилы Громзиной с именем Феодора, инокиня поселилась в заброшенной лесной деревне Куприно (неподалеку от Покровской общины). В марте 2012 года к церкви присоединились две инокини, вышедшие из РПСЦ - Палладия (Нестерович) и Варавара (Глотова), они поселились в Куприно вместе с и[нокиней] Феодорой и образовали Мещерский женский скит, а 18 марта 2012 Феодора была произведена в игуменьи Мещерского скита» (Rossijskaâ Drevlepravoslavnaâ Cerkov' Hristova (Belokrinickaâ ierarhiâ)).

В 2014 году события в Украине, а затем вооруженный конфликт на Донбассе не оставили равнодушным Алимпия (Вербицкого), который заявил о своей поддержке «Украины, восставшей против неосоветчины и властного произвола» (Verbickij, O našem upovanii). Его заявления на политические темы привлекли внимание российских спецслужб, вследствие чего «епископ» Алимпий (Вербицкий) покинул Россию и, переехав в Украину, поселился в Киеве. Его скиты в Рязанской области прекратили свое существование (Alimpij (Verbickij), episkop. O našem upovanii).

По состоянию на 2021 год, юрисдикция Алимпия (Вербицкого) продолжала свою деятельность в рамках служения самого Алимпия (Вербицкого), активно переписывающегося со своими последователями, духовно окормляя тех старообрядцев, которые пожелали остаться под его «омофором». При этом «иерарх» продолжает заниматься графикой и иконописью. Все таинства (кроме Крещения), и обряды в юрисдикции совершаются заоч- 
но, при этом Алимпий (Вербитский) считает свою группу подлинной старообрядческой церковью, «традиционалистами (единственным во всем старообрядчестве)» (Postanovlenie črezvyčajnogo predsobornogo soveŝaniâ Drevlepravoslavnoj Cerkvi Hristovoj Belokrinickoj ierarhii 25 avgusta 2010 g.) и «единственными старообрядческими бескомпромиссными фундаменталистами» (Postanovlenie črezvyčajnogo predsobornogo soveŝaniâ Drevlepravoslavnoj Cerkvi Hristovoj Belokrinickoj ierarhii 25 avgusta 2010 g.). У «епископа» Алимпия имеются собственные антиминсы, используется миро освященное в РПСЦ митрополитом Алимпием (Гусевым) в 1990-х гг. (Postanovlenie črezvyčajnogo predsobornogo soveŝaniâ Drevlepravoslavnoj Cerkvi Hristovoj Belokrinickoj ierarhii 25 avgusta 2010 g.). Информация о количестве клириков и монашествующих - членах юрисдикции не разглашается из соображений безопасности.

Подводя итог описанию данной старообрядческой группы, стоит отметить, что нестроения в среде старообрядчества, иногда выливающиеся в противоборство и обособленное существование, приводимое к возникновению самостоятельных церковных юрисдикций, на протяжении всех четырех сотен лет являются обыденным явлением. Находясь вне орбиты канонической Церкви, противопоставляя себя ей, требуя акривии в вопросах канонического права и догматизирую формы обряда и нормы благочестия, любая церковная община неизменно утрачивает дух мира Христовой правды. Оставшись без него, разрушается и соборное начало. Развивается разномыслие об истине, приводящее к распрям и расколам в среде христиан любых деноминаций. История юрисдикции Алимпия (Вербицкого), побывавшего и монахом Русской Православной Церкви, и иноком Русской Православной Старообрядческой Церкви показывает, что в своей бескомпромиссной борьбе за чистоту исповедания, в поисках юрисдикционной независимости и приемлемых канонических форм для своих сторонников вполне можно отпасть от церковного единства и остаться не только в канонической изоляции, но и просто в одиночестве.

\section{Библиография}

Izbranie Predstoâtelâ Russkoj Pravoslavnoj Staroobrâdčeskoj Cerkvi. (2006). Vestnik Mitropolii.

Kratkaâ biografiâ Vysokopreosvâsennejšego Korniliâ, Mitropolita Moskovskogo i vseâ Rusi. (2005). Pravoslavnyj staroobrâdčeskij cerkovnyj kalendar' 2006. Moskva: Russkaâ Pravoslavnaâ Staroobrâdčeska Cerkov'. s. 119 - 120.

Preosvyashchenneyshiy Andrian, Mitropolit Moskovskiy i vseya Rusi. (2005). Nekrolog. Vestnik Mitropolii. № 4. s. 6 - 9.

546 dnej staroobrâdčestva $v$ XXI veke. Andrian, mitropolit Moskovskij i vseâ Rusi. (2006). Vehi arhipastyrskogo puti. Ermolenko, E. G. (red). Moskva.

Naša Cerkov' v krizise. (2007). Obŝij Dom. № 6 (16). s. 13 - 14. Barmin, M. (2007). Sobor rešil problemu!? - vskryv veny Cerkvi. Obŝij Dom. № $7-8$ (17-18). s. 3 - 9 .

Drevlepravoslavnaâ Cerkov' Hristova (Belokrinickaâ ierarhiâ). [online] http://www.hierarchy.religare.ru/h-orthod-staroob -dch.html, [13.02.2021].

Alimpij (Verbickij), inok. Otkrytoe pis'mo Osvâsennomu Soboru Russkoj Pravoslavnoj Staroobrâdčeskoj Cerkvi. [online] https://drive.google.com/file/d/0Bzp6lcblWLSBeXd DX2J6aUluZ2M/view, [13.02.2021].

Ezerov, A. i Šiškin, A. (2007). Hronika Osvâŝennogo Sobora RPSC 2007 goda glazami ego delegatov. Obŝij Dom. № 7 $8(17-18)$. s. $9-13$.

Eliseev, E. (2007). O poslednih publikaciâh žurnala «Obŝij Dom». Golos" Cerkvi. Vypusk 1. s. 63 - 65. Meŝerskij skit.

Obraŝenie Episkopov Cerkvi Hristovoj. Vestnik Mitropolii. (2008) № 1. s. 5. Moskva.

Postanovlenie Soveta Mitropolii Russkoj Pravoslavnoj Staroobrâdčeskoj Cerkvi (g. Moskva, 26 - 27 fevralâ 2008). Vestnik Mitropolii. (2008). № 1. s. 4 - 5. Moskva.
Hohlov, O. (red.). (2013). Razdory v RPSC XXI vek. O sovremennoj specifike deleniâ Cerkvi na učaŝuû i učimuû. Issledovanie sajta www.STAROVE.RU. s. 27. Moskva.

Rossijskaâ Drevlepravoslavnaâ Cerkov' Hristova (Belokrinickaâ ierarhiâ). [online] http://www.hierarchy.religare.ru/h-orthodstaroob-rdhc.html, [13.02.2021].

Verbickij, A. (2010). Avtobiografičeskij očerk. Golos" Cerkvi. Vypusk 2. s. 20 - 26. Meŝerskij skit.

Portfolio staroobrâdčeskogo episkopa Alimpiâ (Verbickogo). [online] https:/goloscerkvi.info/portfolio-episkopa-alimpiya/, [13.02.2021].

Arkhiyereyskaya khirotoniya svyashchennoinoka Alimpiya (Verbitskogo)//Golos Tserkvi. Meshcherskiy skit, 2010. Vypusk 2. s. $13-19$.

Bočkov, P. (2018). Obzor nekanoničeskih pravoslavnyh ûrisdikcij $X X-X X I$ vv. T. 2: Reformatorskie raskoly: monografiâ. Sankt-Peterburg.

Stavlennaâ gramota № 74 ot 07.07.2010 g. Kopiâ. Pečat'. Podpisi. Na 11 . Arhiv avtora.

Postanovlenie črezvyčajnogo predsobornogo soveŝaniâ Drevlepravoslavnoj Cerkvi Hristovoj Belokrinickoj ierarhii 18 iûlâ 2010 g. Golos" Cerkvi. (2010). Vypusk 2. s. 39. Meŝerskij skit.

Postanovlenie črezvyčajnogo predsobornogo soveŝaniâ Drevlepravoslavnoj Cerkvi Hristovoj Belokrinickoj ierarhii 25 avgusta 2010 g. Golos" Cerkvi. (2010). Vypusk 2. s. 39. Meŝerskij skit.

Alimpij (Verbickij), episkop. O našem upovanii [online] https:// goloscerkvi.info/o-nashem-upovanii-3/, [13.02.2021].

Alimpij (Verbickij), episkop. Ličnoe soobŝenie avtoru ot 16.03. 2021. 